\title{
Just buckle up
}

\author{
Jacob A. Klapper, MD, FACS
}

From the Division of Cardiothoracic Surgery, Duke University Medical Center, Durham, NC.

Disclosures: Author has nothing to disclose with regard to commercial support.

Received for publication March 31, 2018; accepted for publication April 5, 2018; available ahead of print May 10, 2018 .

Address for reprints: Jacob A. Klapper, MD, FACS, Division of Cardiothoracic Surgery, DUMC 3954, Durham, NC 27710 (E-mail: Jacob.klapper@ duke.edu).

J Thorac Cardiovasc Surg 2018;156:806-7

$0022-5223 / \$ 36.00$

Copyright $(2018$ by The American Association for Thoracic Surgery

https://doi.org/10.1016/j.jtcvs.2018.04.017

In their article in this issue of the Journal, Cao and colleagues ${ }^{1}$ conclude that lymph node dissection is associated with better survival of patients undergoing sublobar resection. More importantly, their review of the Surveillance, Epidemiology, and End Results (SEER) database highlights an unfortunate reality that continues to plague the surgical management of lung cancer: insufficient lymph node sampling or dissection at the time of surgery $(44.6 \%$ of patients had no regional lymph nodes removed at the time of surgery). As Cao and colleagues ${ }^{1}$ emphasize, we have ample evidence $^{2}$ to support the routine application of lymph node sampling or dissection. In fact, the importance of this element of the operation is indisputable, just like the concept of achieving negative margins.

Is there something particularly challenging about making nodal sampling or dissection routine in all lung cancer resections? Does the addition of this component to the operation add substantially to morbidity and mortality? Clearly not, yet we continue to read reports in the literature with astounding numbers of cases being performed in the absence of lymph node sampling or dissection. ${ }^{3-5}$ So, how to explain?

Perhaps it is possible to compare this situation to what happens each time we get in a car. If we plan to travel on a busy interstate, we are more apt to buckle up, because we expect to be traveling at high rates of speed. Comparably, as thoracic surgeons, if we have a patient with a 5$\mathrm{cm}$ upper lobe tumor, we appreciate the patient's high risk of nodal involvement and thus the importance of a mediastinal node dissection.

Conversely, some people, forgo putting on their seat belts when getting in the car for a short trip, subconsciously thinking that because they know the roads well and will not be traveling far, the belt is not a necessity. But why not buckle up? It is a quick, simple act with proven benefits. Plus, accidents can happen anywhere, at any speed, and can be deadly. The same must also be said for lymph node sampling at the time of sublobar resection. A small cancer, just like that 5-mile trip to Target, is still a potentially life-limiting entity. For the dedicated thoracic surgeon,

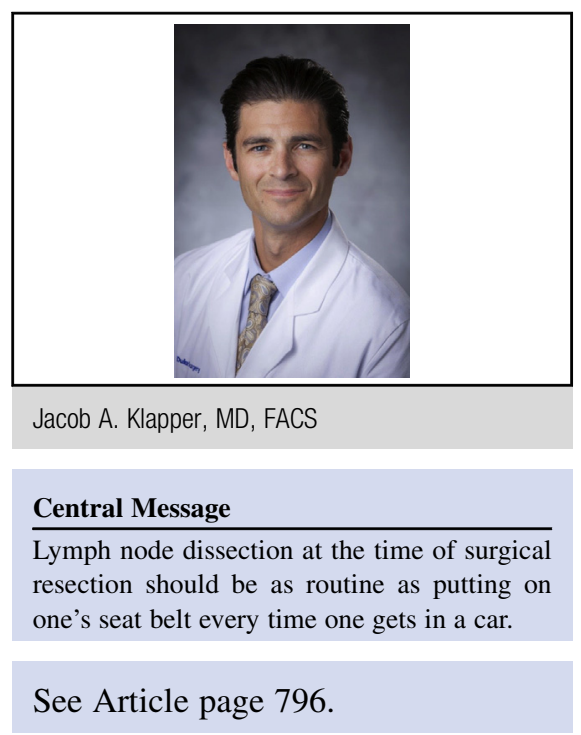

resection in conjunction with a lymph node sampling or dissection should be no more difficult than buckling a seat belt.

In the end, Cao and colleagues, ${ }^{1}$ in addition to reemphasizing the importance of nodal sampling or dissection, attempt to explain why it is not being done. But it is impossible to ascertain this from an entity like the SEER database. Explanations for human behavior that occurs in the face of evidence to the contrary is pervasive in all elements of life. For example, you can remind someone that of the 35,092 people killed in motor vehicle accidents in 2015, 48\% were not wearing seat belts and that seat belts saved 13,941 lives in that same year-and yet there will be those who continue to ride without one. ${ }^{6}$ Likewise, we know that nodal sampling or dissection is essential to staging and impacts treatment-but, as Cao and colleagues ${ }^{1}$ have reminded us, sometimes the easiest things are the hardest things to do.

\section{References}

1. Cao J, Xu J, He Z, Ping Yuan P, Huang S, Lv W, et al. Prognostic impact of Lymphadenctomy on outcomes of sublobar resection for stage IA non-small cell lung cancer $\leq 2 \mathrm{~cm}$. J Thorac Cardiovasc Surg. 2018;156:796-805.e4.

2. Gulack BC, Yang CF, Speicher PJ, Meza JM, Gu L, Wang X, et al. The impact of tumor size on the association of the extent of lymph node resection and survival in clinical stage I non-small cell lung cancer. Lung Cancer. 2015; 90:554-60

3. Allen M, Darling G, Pechet T, Mitchell JD, Herndon JE II, Landreneau RJ, et al; ACOSOG Z0030 Study Group. Morbidity and mortality of major pulmonary resection in patients with early-stage lung cancer: initial results of 
the randomized prospective ACOSOG Z0030 trial. Ann Thorac Surg. 2006; 81:1013-20.

4. Stiles BM, Kamel MK, Nasar A, Harrison S, Nguyen AB, Lee P, et al. The importance of lymph node dissection accompanying wedge resection for clinical stage IA lung cancer. Eur J Cardiothorac Surg. 2017;51:511-7.
5. Speicher P, Gu L, Gulack B, Wang X, D’Amico TA, Hartwig MG, et al. Sublobar resection for clinical stage IA non-small-cell lung cancer in the United Statesc. Clin Lung Cancer. 2016;17:47-55.

6. National Highway Traffic Safety Administration. Available at: www.nhtsa.gov. Accessed April 14, 2018. 